\title{
Diagnostic and therapeutic treatment modalities for acute lower gastrointestinal bleeding: a systematic review
}

\section{(๑) $\odot \ominus$}

\section{Authors}

Kathryn Oakland ${ }^{1}$, Jennifer Isherwood ${ }^{2}$, Conor Lahiff ${ }^{3}$, Petra Goldsmith ${ }^{4}$, Michael Desborough ${ }^{1}$, Katherine S. Colman ${ }^{1}$, Richard Guy ${ }^{5}$, Raman Uberoi ${ }^{6}$, Michael F. Murphy ${ }^{1}$, James E. East ${ }^{3}$, Sally Hopewell7, Vipul Jairath ${ }^{8,9}$

Institutions

1 NHS Blood and Transplant, Oxford, United Kingdom

2 Department of General Surgery, Milton Keynes Hospital, Milton Keynes, United Kingdom

3 Translational Gastroenterology Unit, University of Oxford, John Radcliffe Hospital, Oxford, United Kingdom

4 Department of Transplantation, Royal Liverpool Hospital, Liverpool, United Kingdom

5 Department of Colorectal Surgery, Oxford University Hospitals, Oxford, United Kingdom

6 Department of Interventional Radiology, Oxford University Hospitals, Oxford, United Kingdom

7 Oxford Clinical Trials Research Unit, University of Oxford, Oxford, United Kingdom

8 Division of Epidemiology and Biostatistics, Western University, London, Ontario, Canada

9 Department of Medicine, Division of Gastroenterology, University Hospital, London, Ontario, Canada

submitted 2.5.2017

accepted after revision 10.7.2017

Bibliography

DOI https://doi.org/10.1055/s-0043-117958 |

Endoscopy International Open 2017; 05: E959-E973

(c) Georg Thieme Verlag KG Stuttgart · New York ISSN 2364-3722

\section{Corresponding author}

Vipul Jairath, PhD, Department of Medicine, Division of Gastroenterology, University Hospital, London, Ontario, Canada

Fax: +1-519-9315278

vjairath@uwo.ca

\section{ABSTRACT}

Background and study aims Investigations for lower gastrointestinal bleeding (LGIB) include flexible sigmoidoscopy, colonoscopy, computed tomographic angiography (CTA), and angiography. All may be used to direct endoscopic, radiological or surgical treatment, although their optimal use is unknown. The aims of this study were to determine the diagnostic and therapeutic yields of endoscopy, CTA, and angiography for managing LGIB, and their influence on rebleeding, transfusion, and hospital stay.

Patients and methods A systematic search of MEDLINE, PubMed, EMBASE, and CENTRAL was undertaken to identify randomized controlled trials (RCTs) and nonrandomized studies of intervention (NRSIs) published between 2000 and 12 November 2015 in patients hospitalized with LGIB. Separate meta-analyses were conducted, presented as pooled odds (ORs) or risk ratios (RR) with $95 \%$ confidence intervals (Cls).

Results Two RCTs and 13 NRSIs were included, none of which examined flexible sigmoidoscopy, or compared endotherapy with embolization, or investigated the timing of CTA or angiography. Two NRSIs (57-223 participants) comparing colonoscopy and CTA were of insufficient quality for synthesis but showed no difference in diagnostic yields between the two interventions. One RCT and 4 NRSIs (779 participants) compared early colonoscopy (<24 hours) with colonoscopy performed later; meta-analysis of the NRSIs demonstrated higher diagnostic and therapeutic yields with early colonoscopy (OR $1.86,95 \% \mathrm{Cl} 1.12$ to 2.86, $P=0.004$ and OR $3.08,95 \% \mathrm{Cl} 1.93$ to $4.90, P<0.001$, respectively) and reduced length of stay (mean difference 2.64 days, $95 \% \mathrm{Cl} 1.54$ to 3.73 ), but no difference in transfusion or rebleeding.

Conclusions In LGIB there is a paucity of high-quality evidence, although the limited studies on the timing of colonoscopy suggest increased rates of diagnosis and therapy with early colonoscopy. 


\section{Introduction}

Acute lower gastrointestinal bleeding (LGIB) has an estimated incidence of 33/100000 but is associated with greater resource use than upper GI bleeding [1]. The management of LGIB involves determining the source of bleeding in order to direct the most appropriate intervention to achieve hemostasis. There are multiple choices of intervention, including flexible sigmoidoscopy, colonoscopy, computed tomographic angiography (CTA), mesenteric angiography, and nuclear scintigraphy. The diagnostic and subsequent therapeutic yields are unclear and are likely to be influenced by multiple patient factors $[2,3]$ and the timing of intervention [4]. There is little evidence in the literature informing the optimal use of these interventions; hence, the development of recommendations in guidelines is limited [5].

As well as diagnosis, endoscopy offers endotherapy, including adrenaline injection, thermocoagulation or clipping. Extravasation of contrast on CTA or mesenteric angiography may identify bleeding that is amenable to embolization. Compared with colonoscopy, CTA is better tolerated by patients but may identify a source only where there is active bleeding [6]. Delays between CTA and angiography may lead to a blush on CTA becoming nonapparent on a subsequent mesenteric angiogram [7].

Given uncertainties around the optimum initial approach to investigation and management, we conducted a systematic review of the diagnostic and therapeutic yields of flexible sigmoidoscopy, colonoscopy, CTA, and mesenteric angiography for LGIB. This takes the form of several direct head-to-head comparisons between modalities, each of which is reported separately, aiming to mirror the clinical questions encountered by clinicians involved in the acute management of LGIB.

\section{Patients and methods}

This review was registered on the PROSPERO register of systematic reviews (CRD42016025100) and conducted in accordance with the preferred reporting items for systematic review and meta-analysis (PRISMA) statement [8] and Meta-Analysis of Observational Studies in Epidemiology (MOOSE) group [9].

\section{Search strategy}

We searched MEDLINE, PubMed, EMBASE, CDSR, CENTRAL, DARE, HTA, NHSEED, ClinicalTrials.gov, and the WHO International Clinical Trials Registry Platform for articles published between 1 January 2000 and 12 November 2015 without language restrictions (see Appendix 1 for search strategy). The search was limited to publications since 2000 owing to the more recent adoption of CTA and therapeutic endoscopy, reflective of modern day practice.

\section{Study eligibility}

Eligible studies were randomized controlled trials (RCTs) and cohort studies (nonrandomized studies of intervention [NRSIs]). As there is variation in the reporting quality of NRSIs, those with a cohort design without methodological concor- dance were screened to ascertain whether they met the criteria to be categorized as a cohort study as described by Dekkers et al. [10].

Adults hospitalized with acute LGIB of any cause were eligible. Studies of upper GI bleeding or pediatric populations were ineligible. LGIB was defined as "the onset of hematochezia originating from either the colon or the rectum" [5]. This can manifest as red or maroon blood, or melena [11]. As the focus of this review was the immediate investigation and treatment of LGIB, studies of patients who had completed first-line investigations (colonoscopy, esophagogastroduodenoscopy, and radiological studies) without a proven source of bleeding, such as those with obscure GI bleeding [12], were excluded.

Interventions included flexible sigmoidoscopy, colonoscopy, CTA, mesenteric angiography, therapeutic endoscopy, and mesenteric embolization. Comparisons were grouped into three themes: choice of investigation, timing of investigation, and choice of treatment. Choice of investigation comparisons comprised: flexible sigmoidoscopy vs. CTA, colonoscopy vs. CTA, colonoscopy/flexible sigmoidoscopy vs. other (e.g. standard care), CTA vs. other. Timing of investigation comprised early vs. late flexible sigmoidoscopy, colonoscopy, CTA, and mesenteric angiography in relation to presentation with bleeding. To maximize study eligibility we did not pre-specify "early" and "late." Choice of treatment comprised endoscopic hemostasis vs. embolization, endoscopic hemostasis vs. other (e.g. surgery), and embolization vs. other. Specific types of endoscopic therapy were also compared. Where applicable, subgroups populated by hemodynamic status were also compared.

\section{Outcomes}

Primary outcomes were diagnostic and therapeutic yields. Therapeutic yield was defined as the proportion of participants that received hemostatic therapy, either during or after the intervention. Secondary outcomes were rebleeding, red blood cell transfusion, length of hospital stay, mortality, and complications related to the intervention.

Two reviewers screened studies and extracted data independently. Study screening and data extraction were performed using Covidence Systematic Review Software (Veritas Heath Innovation Ltd., Melbourne, Australia).

Risk of bias in RCTs and NRSIs was assessed using the Cochrane risk of bias tool [13] and the Newcastle-Ottawa Scale [14], respectively.

\section{Statistical analysis}

Continuous outcomes were compared using mean difference and $95 \%$ confidence intervals (Cls). Dichotomous outcomes were analyzed using risk ratio (RR) and $95 \% \mathrm{Cl}$ for RCTs, and odds ratio (OR) and $95 \% \mathrm{Cl}$ for NRSIs. Where the number of observed events was small, Peto OR and $95 \% \mathrm{Cl}$ were used.

RCTs and NRSIs were analyzed separately [13]. NRSIs were deemed comparable if they had a Newcastle-Ottawa score $\geq 8$ [15]. Meta-analysis was conducted to calculate pooled RR, OR or mean difference, and $95 \% \mathrm{Cl}$ for each comparator. Statistical heterogeneity was analyzed using $l^{2}$ statistics, and values $>50 \%$ were considered to be significantly heterogeneous [16]. We 
used random effects modeling for all NRSIs and presented OR regardless of heterogeneity. No tests for funnel plot asymmetry were undertaken, as the number of studies in each comparison was fewer than 10 [13]. Meta-analysis was undertaken using Review Manager 5.3 (Cochrane Collaboration, Copenhagen, Denmark).

\section{Results}

Searches identified 5879 potentially eligible references and 40 from 2410 prescreened records ( $\mathbf{F i g}$. 1). On full-text review, 507 studies were excluded (reasons shown in $>$ Fig. 1) leaving 2 RCTs, 13 NRSIs, and 2 ongoing studies, including 6 conference abstracts [17-22].

\section{Characteristics of reviewed studies}

There was a lack of data across all interventions and comparators, notably no RCTs or NRSIs comparing embolization with endoscopic hemostasis. There were no studies that included flexible sigmoidoscopy as a comparator. Comparisons between colonoscopy and CTA were limited to nonrandomized data ( $\triangleright$ Table 1 ). A total of 10 studies compared different interventions and five examined different timings of the same intervention. Case definitions of LGIB are included in Appendix 2. A total of 11 studies included patients with LGIB of any cause [4, $18-20,23-29]$ and four were limited to patients with diverticular bleeding $[17,21,22,30]$. The number of participants enrolled in each study ranged from 72 to 100 in the RCTs, and from 27 to 326 in the NRSIs.

Most studies were conducted in older patients and, where reported, anticoagulant, nonsteroidal anti-inflammatory drugs, and particularly antiplatelet use was common. Only four studies reported baseline hemodynamic status [4, 26, 27 , 29].

\section{Choice of investigation}

\section{Colonoscopy vs. CTA}

No RCTs compared colonoscopy with CTA. The two eligible NRSIs were retrospective, one comparing early colonoscopy and CTA (within 24 hours of admission) with early colonoscopy alone in 223 participants [26], and one comparing early colonoscopy with CTA (timings not defined) in a single cohort of 57 patients with diverticular bleeding who underwent both tests [21].

The was no difference in the diagnostic yield of CTA combined with colonoscopy vs. colonoscopy alone (OR 1.31, $95 \%$ $\mathrm{Cl} 0.26$ to 6.63$)$, although the diagnosis of lesions with active bleeding, adherent clot or visible vessels was higher in the CTA group (OR 2.14, 95\% CI 1.16 to 3.95, 223 participants) [26]. Patients in this group subsequently received more endoscopic hemostatic treatment (OR 3.47, $95 \% \mathrm{Cl} 1.74$ to 6.91 ), but there was no difference in terms of rebleeding (OR $1.08,95 \% \mathrm{Cl} 0.51$ to 2.28 ) or the number of participants receiving transfusion (OR $1.71,95 \% \mathrm{Cl} 0.86$ to 3.39). Mortality, length of hospital stay, and complications were not reported. The study by Yabutani et al. [21] described only diagnostic yield, demonstrating

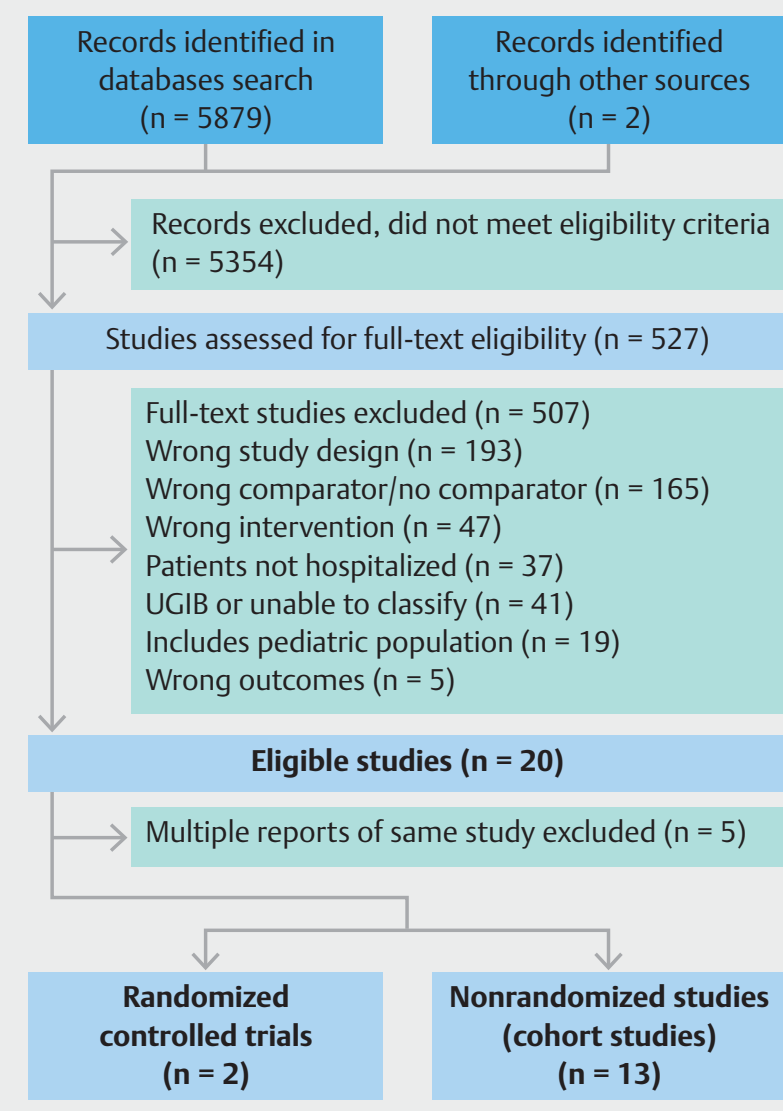

- Fig. 1 PRISMA flow chart. UGIB, upper gastrointestinal bleeding.

no difference between CTA and colonoscopy (OR 1.36, $95 \% \mathrm{Cl}$ 0.63 to $2.95,57$ participants).

\section{Colonoscopy vs. other}

We identified one RCT [4] that randomized 100 patients to colonoscopy within 8 hours or standard care (red cell scanning, angiography or elective colonoscopy). The diagnostic yield was higher in the group randomized to urgent colonoscopy (RR $1.91,95 \% \mathrm{Cl} 1.03$ to 3.53 ), but there was no difference in therapeutic yield (endoscopic hemostasis or vasopressin infusion at angiography: RR $1.7,95 \% \mathrm{Cl} 0.87$ to 3.34 ) or rebleeding (RR $0.73,95 \% \mathrm{Cl} 0.37$ to 1.44 ), although volume of transfusion was smaller in the urgent colonoscopy group (mean difference -0.8 units, $95 \% \mathrm{Cl}-0.62$ to -0.98$)$. We identified one NRSI [23]: a study of 111 participants who underwent ultrasound followed by colonoscopy. The diagnostic yield of colonoscopy was superior to that of ultrasound (OR $3.78,95 \% \mathrm{Cl} 2.07$ to 6.91 ).

\section{CTA vs. other}

No RCTs were identified. The three eligible NRSIs all compared CTA with nuclear scintigraphy; two retrospective cohort studies of 92 - 99 participants $[18,20]$, and one before and after study of a protocol that prioritized CTA over nuclear scintigraphy in 161 participants [25]. Ketwaroo et al. [18] demonstrated a higher diagnostic yield with the use of CTA (OR 4.03, $95 \% \mathrm{Cl}$ 
- Table 1 Summary of evidence by comparison investigated and study methodology.

\begin{tabular}{|c|c|c|c|}
\hline Comparator & RCTs [ref] & NRSIs [ref] & Ongoing trials \\
\hline \multicolumn{4}{|l|}{ Choice of investigation } \\
\hline Flexible sigmoidoscopy vs. CTA & None & None & \\
\hline Flexible sigmoidoscopy vs. other & None & None & \\
\hline Colonoscopy vs. CTA & None & $\begin{array}{l}\text { Nagata } 2015[26] \\
\text { Yabutani } 2014[21]\end{array}$ & \\
\hline Colonoscopy vs. other (e. g. standard care) & Green 2005 [4] & Yamaguchi 2006 [23] & \\
\hline CTA vs. other & None & $\begin{array}{l}\text { Ketwaroo } 2012[18] \\
\text { Sun } 2011[20] \\
\text { Jacovides } 2015[25]\end{array}$ & \\
\hline Diagnostic mesenteric angiography vs. other & None & None & \\
\hline \multicolumn{4}{|l|}{ Timing of first-line investigation } \\
\hline $\begin{array}{l}\text { Colonoscopy: } \\
\text { Early (<24 hours) vs. late ( }>24 \text { hours) }\end{array}$ & Laine 2010 & $\begin{array}{l}\text { Abeldawi } 2014 \text { [24] } \\
\text { Nagata } 2016 \text { [27] } \\
\text { Strate } 2003 \text { [28] } \\
\text { Rodriguez-Moranta } 2007 \text { [19] }\end{array}$ & \\
\hline $\begin{array}{l}\text { Radiology: } \\
\text { A) Urgent CTA vs. nonurgent } \\
\text { B) Urgent mesenteric angiography vs. nonurgent }\end{array}$ & $\begin{array}{l}\text { None } \\
\text { None }\end{array}$ & $\begin{array}{l}\text { None } \\
\text { None }\end{array}$ & \\
\hline \multicolumn{4}{|l|}{ Choice of treatment } \\
\hline Therapeutic endoscopy vs. mesenteric embolization & None & None & \\
\hline Therapeutic endoscopy vs. other & None & Jensen 2000 [30] & $\begin{array}{l}\text { Matsuhashi } \\
\text { JPRN-UMIN000008287 }\end{array}$ \\
\hline Embolization vs. other & None & None & \\
\hline Endoscopic agent A vs. B & None & $\begin{array}{l}\text { Nakano } 2015 \text { [22] } \\
\text { Ishii } 2011 \text { [17] }\end{array}$ & $\begin{array}{l}\text { Barkun } \\
\text { NCT02135627 }\end{array}$ \\
\hline
\end{tabular}

1.67 to 9.72 , 92 participants) but the study by Sun et al. [20] reported no difference between modalities (OR $0.49,95 \% \mathrm{Cl}$ 0.20 to $1.21,99$ participants). Neither study reported therapeutic yield for both study arms or any of the secondary outcomes. The protocol study by Jacovides et al. [25] demonstrated no difference in diagnostic yield (OR $0.85,95 \% \mathrm{Cl} 0.33$ to 2.19), therapeutic yield (defined as embolization during first mesenteric angiography, $\mathrm{OR} 1.10,95 \% \mathrm{Cl} 0.55$ to 2.20 ) or length of hospital stay (mean difference 3 days, $95 \% \mathrm{Cl}-16.58$ to 22.58$)$.

\section{Diagnostic mesenteric angiography vs. other}

We found no studies that included mesenteric angiography as a first-line intervention.

\section{Timing of first-line investigation}

\section{Colonoscopy}

One RCT [29], one prospective [19], and three retrospective NRSIs [24,27,28] compared early and late colonoscopy. The RCT by Laine et al. included 72 patients. The NRSI ranged from 57 to 326 participants. Early colonoscopy was defined as within
12 hours by one study [29] and within 24 hours by three studies [19, 24,27]. One study subdivided cohorts into consecutive 12 hours groups [28]. For the purpose of this comparison, early colonoscopy is defined as that performed within 24 hours of admission.

When assessing diagnostic yield, three studies categorized diverticula [27-29] or hemorrhoids [28,29] as a definite (based on the presence of active bleeding or stigmata of recent hemorrhage) or presumptive (presence of diverticulosis or hemorrhoids without bleeding in absence of other potential bleeding sources) cause of bleeding. Rodriguez-Moranta et al. [19] reported only definite diagnoses, but did not define these, and Albeldawi et al. [24] did not define diagnosis.

When presumptive and definite diagnoses are included in diagnostic yield, no difference was observed between early vs. late colonoscopy in the RCT (RR $1.17,95 \% \mathrm{Cl} 0.87$ to 1.56 ) or pooled analysis of the NRSIs (OR $0.68,95 \% \mathrm{Cl} 0.31$ to $1.49,3$ studies, 527 participants, $R^{2}=9 \%$, $>$ Fig. 2 ). When diagnostic yield was limited to definite diagnoses, early colonoscopy was associated with a higher diagnostic yield in the NRSIs (OR $1.86,95 \% \mathrm{Cl} 1.21$ to $2.86,3$ studies, 527 participants $I^{2}=42 \%$, 


\begin{tabular}{|c|c|c|c|c|c|c|c|c|}
\hline \multirow[b]{2}{*}{ Study or subgroup } & \multicolumn{4}{|c|}{ Early colonoscopy Late colonoscopy } & \multirow{2}{*}{$\begin{array}{l}\text { Odds Ratio } \\
\text { M-H, Random, } 95 \% \mathrm{CL}\end{array}$} & \multirow{2}{*}{\multicolumn{2}{|c|}{$\begin{array}{l}\text { Odds Ratio } \\
\text { M-H, Random, } 95 \% \mathrm{CL}\end{array}$}} & \\
\hline & Events & Total & Events & Total Weight & & & & \\
\hline \multicolumn{9}{|c|}{ Presumptive and definite diagnoses } \\
\hline Strate 2003 & 60 & 69 & 68 & $7547.6 \%$ & $0.69(0.24,1,96)$ & - & & \\
\hline Nagata 2015a & 156 & 163 & 161 & $16322.5 \%$ & $0.28(0.06,1.35)$ & & - & \\
\hline Abeldawi 2014 & 20 & 24 & 26 & $3329.9 \%$ & $1.35(0.35,5.24)$ & & $\rightarrow$ & \\
\hline Subtotal $(95 \% \mathrm{Cl})$ & & 256 & & 271100.0 & $0.68(0.31,1.49)$ & & 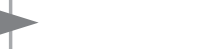 & \\
\hline Total events & 236 & & 255 & & & & & \\
\hline \multicolumn{9}{|c|}{ Heterogenity: $\mathrm{Tau}^{2}=0.05 ; \mathrm{Chi}^{2}=2.21, \mathrm{df}=2(P=0.33) ; \mathrm{I}^{2}=9 \%$} \\
\hline \multicolumn{9}{|c|}{ Test for overall effect $Z=0.95(P=0.34)$} \\
\hline \multicolumn{9}{|l|}{ Definite diagnosis only } \\
\hline Strate 2003 & 37 & 69 & 25 & $7526.7 \%$ & $2.31(1.18,4,54)$ & & $\longrightarrow$ & \\
\hline Rodriguez-Moranta 200 & 00762 & 92 & 40 & $8830.6 \%$ & $2.48(1.35,4.54)$ & & $\longrightarrow$ & \\
\hline Nagata 2015a & 103 & 163 & 92 & $16342.7 \%$ & $1.32(0.85,2.07)$ & & H & \\
\hline Subtotal $(95 \%$ Cl) & & 324 & & 326100.0 & $1.86(1.21,2.86)$ & & & \\
\hline Total events & 202 & & 157 & & & & & \\
\hline \multicolumn{9}{|c|}{ Heterogenity: $\mathrm{Tau}^{2}=0.06 ; \mathrm{Chi}^{2}=3.43, \mathrm{df}=2(P=0.18) ; 1^{2}=42 \%$} \\
\hline \multicolumn{9}{|c|}{ Test for overall effect $Z=2.85(P=0.004)$} \\
\hline & & & & & 0.05 & 0.2 & 5 & \\
\hline & & & & & & te colonoscopy & Favors early colc & \\
\hline
\end{tabular}

> Fig. 2 Forest plot of comparison of nonrandomized studies of intervention. Upper: Presumptive plus definite diagnoses. Lower: Definite diagnoses only. Definitive diagnoses were defined by the presence of stigmata of recent hemorrhage or active bleeding, plus the diagnosis of an underlying cause. $\mathrm{Cl}$, confidence interval; $\mathrm{M}-\mathrm{H}$, Mantel-Haenszel.

- Fig. 2), although this was not significant in the RCT (RR 1.12, $95 \% \mathrm{Cl} 0.70$ to 1.78$)$.

All studies defined therapeutic yield as the number of participants receiving endoscopic therapy. All employed endoscopic hemostasis with a minimum of three available modalities (clipping, banding, thermocoagulation, argon plasma coagulation, adrenaline injection), the specific type depending on pathology and endoscopist preference. The therapeutic yield was superior in the early colonoscopy group in the pooled analysis of the NRSIs (OR 3.08, $95 \% \mathrm{Cl} 1.93$ to 4.90, 4 studies, 707 participants $R=7 \%$, Fig. 3a), but no different in the RCT (RR $1.0,95 \% \mathrm{Cl}$ 0.36 to 2.81 ).

Rebleeding was reported in the RCT [29] and two NRSIs $[24,27]$, but all varied in their definition ( $>$ Table 2 ) so were not pooled. There was no difference in rebleeding between early and late colonoscopy in the RCT (RR 1.6, $95 \% \mathrm{Cl} 0.58$ to 4.43 , 72 participants), or the NRSIs (Nagata et al. OR $1.96,95 \% \mathrm{Cl}$ 0.94 to $4.11,326$ participants, and Albeldawi et al. OR 0.7, 95 $\% \mathrm{Cl} 0.2$ to $2.44,57$ participants).

Transfusion was reported in the RCT [29] and one NRSI [27]; patients in the early group of the RCT received more transfusions (mean difference 0.8 units, $95 \% \mathrm{Cl} 0.65$ to 0.95 , 72 participants), but in the NRSI there was no difference in the number of participants receiving transfusion (OR $1.00,95 \% \mathrm{Cl} 0.62$ to 1.63, 326 participants).
Mean length of hospital stay was reported in three studies [19, 27, 29]. Early colonoscopy was associated with a shorter hospital stay in NRSIs (mean difference 2.64 days, $95 \% \mathrm{Cl} 1.54$ to 3.73 , two studies, 506 participants, $P^{2}=0 \%$ ) and in the RCT (mean difference 0.40 days, $95 \% \mathrm{Cl} 0.06$ to $0.74,72$ participants) ( Fig. 3b).

Adverse events were reported in two studies [27, 29]. Laine et al. [29] reported one perforation in the late colonoscopy group (RR $0.33,95 \% \mathrm{Cl} 0.01$ to 7.92 ). Nagata et al. [27] reported no major colonoscopy-related adverse events in either cohort. Mortality was reported in two studies [24,29]. There were no deaths in the study by Albeldawi et al. [24], but there were two deaths in the urgent colonoscopy arm in the RCT by Laine et al. (RR 5.00, $95 \% \mathrm{Cl} 0.25$ to 1.00). One patient developed a fatal intracranial hemorrhage, and the other required prolonged hospitalization due to medical co-morbidities and died after a cardiorespiratory arrest.

\section{CTA and mesenteric angiography}

We found no studies comparing early vs. late CTA or mesenteric angiography.

\section{Choice of treatment}

Therapeutic endoscopy vs. mesenteric embolization We found no studies. 
- Table 2 Interstudy variability of the definition of rebleeding.

\begin{tabular}{|c|c|}
\hline Study [ref] & Definition of rebleeding \\
\hline Green 2005 [4] & $\begin{array}{l}\text { Hematochezia (defined as any one of }>3 \text { bloody bowel movements in }<8 \text { hours, ICU admission, }>5 \% \text { decrease in Hct in } \\
<12 \text { hours, transfusion of }>3 \text { units RBC, hemodynamic instability in previous } 6 \text { hours defined as angina, syncope, pre-syn- } \\
\text { cope, orthostatic vital signs, MAP }<80 \mathrm{mmHg} \text { or } \mathrm{HR}>110 \text { ) after clinical cessation of the index bleeding event }\end{array}$ \\
\hline Laine 2010 [29] & $\begin{array}{l}\text { Hematochezia persisting for }>24 \text { hours, recurrent hematochezia after initial resolution (e. g. brown stool followed by hema- } \\
\text { tochezia), } H R>100 \text { or } S B P<100 \mathrm{mmHg} \text { after hemodynamic stability for } \geq 1 \text { hour, or hemoglobin drop }>2 \mathrm{~g} / \mathrm{dL} \text { after stable } \\
\text { hemoglobin values } \geq 3 \text { hours apart }\end{array}$ \\
\hline Nagata 2016 [27] & $\begin{array}{l}\text { Significant amounts of fresh bloody or wine-colored stools after index colonoscopy with unstable vital signs; } \mathrm{SBP} \leq 90 \mathrm{mmHg} \\
\text { or } \mathrm{HR} \geq 110 \text { or the need for blood transfusion }\end{array}$ \\
\hline Strate 2003 [28] & $\begin{array}{l}\text { Blood per rectum after } 24 \text { hours of stability accompanied by a drop in } \mathrm{Hct} \geq 20 \% \text {, and/or a requirement of additional blood } \\
\text { transfusions }\end{array}$ \\
\hline Abeldawi 2014 [24] & After clinical cessation of index bleeding event during hospitalization \\
\hline Nagata 2015 [26] & $\begin{array}{l}\text { Significant fresh bloody or wine-colored stool accompanied by unstable vital signs; } S B P \leq 90 \mathrm{mmHg} \text { or HR } \geq 110 \text { and nonre- } \\
\text { sponse to } \geq 2 \text { units transfused blood }\end{array}$ \\
\hline Jensen 2000 [30] & $\begin{array}{l}\text { Self-limited or recurrent hematochezia that required no more than an additional } 2 \text { units of packed red cells or continued or } \\
\text { recurrent hematochezia that required at least } 3 \text { units of packed red cells }\end{array}$ \\
\hline Ishii $2011[17]$ & Clinical evidence of recurrent bleeding \\
\hline
\end{tabular}

\section{a Therapeutic yield}

\begin{tabular}{lrrrrrrr} 
& \multicolumn{3}{c}{ Early colonoscopy Late colonoscopy } & \multicolumn{2}{l}{ Odds Ratio } \\
Study or subgroup & Events & Total & Events & Total & Weight & M-H, Random, 95 \\
\hline Abeldawi 2014 & 17 & 24 & 17 & 33 & $16.5 \%$ & $2.29(0.75,6,96)$ \\
Nagata 2015a & 42 & 163 & 14 & 163 & $43.9 \%$ & $3.69(1.93,7.08)$ \\
Rodriguez-Moranta 2007 & 21 & 92 & 11 & 88 & $30.6 \%$ & $2.07(0.93,4.60)$ \\
Strate 2003 & 13 & 69 & 2 & 75 & $9.0 \%$ & $8.47(1.84,39.09)$ \\
Total (95\% Cl) & & 348 & & 359 & $100.0 \%$ & $3.08(1.93,4.90)$ \\
Total events & 93 & & 44 & & &
\end{tabular}

Heterogenity: $\operatorname{Tau}^{2}=0.02 ; \mathrm{Chi}^{2}=3.24, \mathrm{df}=3(P=0.36) ; \mathrm{I}^{2}=7 \%$

Test for overall effect $Z=4.74(P<0.00001)$

\section{b Length of stay}

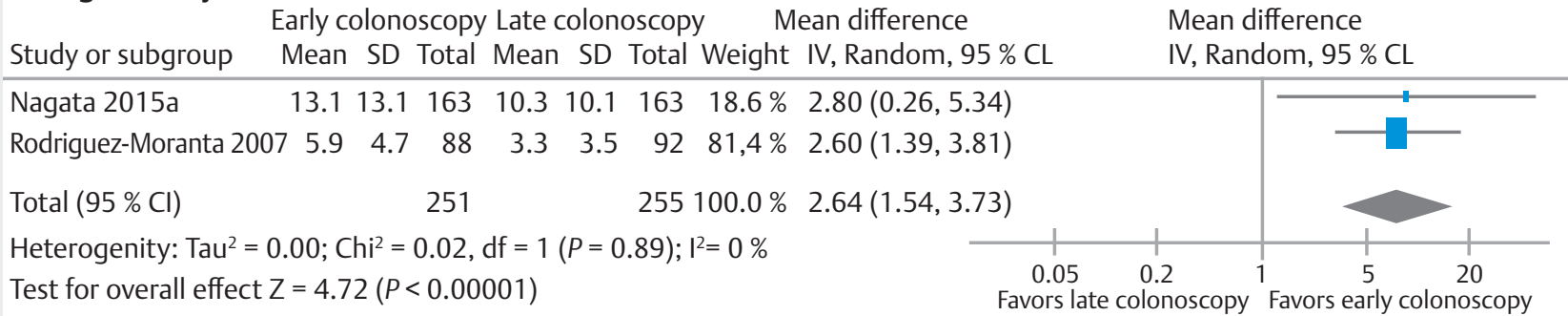

- Fig. 3 Forest of plot of comparison of nonrandomized studies of intervention. a Therapeutic yield. b Length of hospital stay. $\mathrm{Cl}$, confidence interval; M-H, Mantel-Haenszel.

Therapeutic endoscopy vs. other

One NRSI compared endoscopic therapy (adrenaline injection or thermocoagulation) with a historical control comprising conservative or surgical treatment in patients with diverticular bleeding [30]. Patients who received endoscopic treatment were less likely to require surgery for bleeding (Peto OR 0.14 , $95 \% \mathrm{Cl} 0.02$ to $0.88,27$ participants), rebleed (Peto OR 0.10, $95 \% \mathrm{Cl} 0.02$ to 0.51 ) or receive a transfusion (Peto OR 0.10, 95 $\% \mathrm{Cl} 0.02$ to 0.51 ). We identified one ongoing RCT comparing 
- Table 3 Assessment of methodological quality (Cochrane risk of bias for RCTs, Newcastle-Ottawa for NRSIs).

\begin{tabular}{|c|c|c|c|c|c|c|c|}
\hline RCT [ref] & $\begin{array}{l}\text { Sequence } \\
\text { genera- } \\
\text { tion }\end{array}$ & $\begin{array}{l}\text { Allocation } \\
\text { conceal- } \\
\text { ment }\end{array}$ & $\begin{array}{l}\text { Blinding of } \\
\text { participants } \\
\text { and personnel }\end{array}$ & $\begin{array}{l}\text { Blinding of out- } \\
\text { come assessors }\end{array}$ & $\begin{array}{l}\text { Incom- } \\
\text { plete out- } \\
\text { come data }\end{array}$ & $\begin{array}{l}\text { Selective } \\
\text { outcome } \\
\text { reporting }\end{array}$ & Other \\
\hline Green 2005 [4] & Low & Unclear & High & Unclear & Low & Unclear & Low \\
\hline Laine 2010 [29] & Low & Low & High & High & Low & Low & High \\
\hline NRSI [ref] & $\begin{array}{l}\text { Represen- } \\
\text { tativeness } \\
\text { (1) }\end{array}$ & $\begin{array}{l}\text { Selection } \\
\text { of non-ex- } \\
\text { posed (1) }\end{array}$ & $\begin{array}{l}\text { Ascertainment } \\
\text { of exposure (1) }\end{array}$ & $\begin{array}{l}\text { Outcome of inter- } \\
\text { est not present at } \\
\text { start of study (1) }\end{array}$ & $\begin{array}{l}\text { Compar- } \\
\text { ability (2) }\end{array}$ & $\begin{array}{l}\text { Assessment } \\
\text { of outcome } \\
(1)\end{array}$ & $\begin{array}{l}\text { Follow-up long } \\
\text { enough and } \\
\text { adequate ( } 2 \text { ) }\end{array}$ \\
\hline $\begin{array}{l}\text { Adeldawi } 2014 \\
\text { [24] }\end{array}$ & 1 & 1 & 1 & 1 & $1 / 0$ & 1 & $1 / 1$ \\
\hline Ishii 2011 [17] & 0 & 1 & 1 & 1 & $0 / 0$ & 1 & $1 / 1$ \\
\hline $\begin{array}{l}\text { Jacovides } 2015 \\
\text { [25] }\end{array}$ & 1 & 1 & 1 & 0 & $0 / 1$ & 1 & $1 / 1$ \\
\hline Jensen 2000 [30] & 0 & 1 & 1 & 1 & $0 / 0$ & 1 & $1 / 1$ \\
\hline Nagata 2016 [27] & 1 & 1 & 1 & 1 & $1 / 1$ & 1 & $1 / 1$ \\
\hline Nagata 2015 [26] & 1 & 1 & 1 & 1 & $1 / 0$ & 1 & $1 / 1$ \\
\hline Nakano 2015 [22] & 0 & 1 & 1 & 1 & $0 / 0$ & 1 & $1 / 0$ \\
\hline Sun 2011 [20] & 0 & 0 & 1 & 1 & $0 / 0$ & 1 & $1 / 1$ \\
\hline $\begin{array}{l}\text { Yabutani } 2014 \\
\text { [21] }\end{array}$ & 0 & 1 & 1 & 0 & $1 / 1$ & 1 & $1 / 1$ \\
\hline $\begin{array}{l}\text { Yamaguchi } 2006 \\
\text { [23] }\end{array}$ & 1 & 1 & 1 & 1 & $1 / 1$ & 1 & $1 / 1$ \\
\hline $\begin{array}{l}\text { Ketwaroo } 2012 \\
\text { [18] }\end{array}$ & 0 & 0 & 1 & 1 & $0 / 0$ & 1 & $1 / 1$ \\
\hline Strate 2003 [28] & 1 & 1 & 1 & 1 & $1 / 1$ & 1 & $1 / 1$ \\
\hline $\begin{array}{l}\text { Rodriguez-Moran- } \\
\text { ta } 2007 \text { [19] }\end{array}$ & 1 & 1 & 1 & 1 & $1 / 1$ & 1 & $1 / 1$ \\
\hline
\end{tabular}

endoscopic therapy with barium impaction for diverticular bleeding (Matsuhashi et al, JPRN-UMIN000008287).

\section{Mode of endoscopic hemostasis}

No RCTs were identified. Two retrospective NRSIs were identified, both comparing endoscopic band ligation with endoclipping in diverticular bleeding $[17,22]$. The primary outcome in both studies was re-bleeding; Ishii et al. [17] reported 60-day rates of $1 / 16(6.2 \%)$ for endoscopic band ligation and $16 / 48$ (33.3\%) for endoclipping, although this was not significantly different (OR $7.50,95 \% \mathrm{Cl} 0.91$ to $61.94,64$ participants). In the endoclipping group, seven patients required radiological control of bleeding vs. none in the endoscopic band ligation group; however, this was not significant (Peto OR 4.37, $95 \% \mathrm{Cl}$ 0.72 to 26.37). Nakano et al. [22] followed patients for 2 years and also found that large numbers of patients re-bled in each group (endoscopic band ligation 24/50, 48.0\%; endoclipping $18 / 39,46.2 \%$ ), although there was no difference between the two modalities (OR $0.9395 \% \mathrm{Cl} 0.40$ to $2.15,89$ participants). Need for further procedure was not reported. No patient experienced complications related to endoscopy in either study.
We identified one ongoing RCT comparing TC-325 (Hemospray) monotherapy at endoscopy with standard endoscopic therapy in patients with upper GI bleeding or LGIB due to malignancy (Barkun et al., NCT02135627).

\section{Hemodynamic status}

We identified no RCTs, NRSIs or ongoing trials that compared flexible sigmoidoscopy, colonoscopy, CTA or mesenteric angiography in groups stratified by hemodynamic status.

\section{Assessment of methodological quality}

Both RCTs were deemed at high or unclear risk of bias due to blinding ( $\triangleright$ Table 3 ). Laine et al. stated that their trial was not blinded. Green et al. also stated that the physicians caring for the patients were not blinded and gave no detail on blinding of outcome assessors. The nature of the interventions used in these studies makes blinding difficult. For subjective outcomes such as diagnostic yield this may introduce significant bias.

Rebleeding may also be subject to bias due to lack of blinding. Additionally, there was considerable interstudy variation in the definition of rebleeding in the eight studies that reported 
this outcome ( $>$ Table 2 ). Most studies used a definition that included a period of clinical stability $[4,28,29]$, although some did not define the criteria that would need to be met to establish a new bleeding event $[17,24]$. Three studies characterized rebleeding by the persistence of ongoing signs of bleeding without a period of stability $[26,27,30]$, but these definitions may have also captured patients with failed hemostatic intervention, rather than true rebleeding.

One study did not define rebleeding [22].

The study by Laine et al. was subject to "other" source of bias, as it was terminated early because the hospital changed its protocol on allowing colonoscopy in the emergency room, although the reasons for this were not given.

Risk of bias in the NRSIs was assessed using the NewcastleOttawa scale. The two most common areas of poor performance in the NRSIs were selection of participants, particularly representativeness of the exposed, and comparability of cohorts. Six studies scored poorly for representativeness of LGIB as they studied a single pathology $[17,21,22,30]$ or a single intervention that was related to severity of bleeding $[18,20]$. This limits interstudy comparability and the generalizability of these results to the LGIB population as a whole.

Three studies did not include data on whether they adjusted for confounders $[17,18,20]$, one study provided no data on confounders and also populated one treatment arm using an intervention that is likely to be related to severity of bleeding (endoscopic hemostasis) [30], and one study compared baseline demographics for each group, but did not include cardiovascular parameters or baseline transfusion requirements [22]. There are likely to be significant baseline imbalances between the cohorts in these studies. None were deemed of sufficient quality to permit data synthesis.

\section{Discussion}

There is considerable uncertainty regarding the optimal management of LGIB [5]. This is a comprehensive review encompassing all of the major diagnostic and treatment modalities for LGIB, and demonstrating a lack of evidence across the majority of interventions. The area with the most evidence is timing of colonoscopy, with meta-analysis suggesting higher diagnostic yields, rates of hemostasis, and a reduction in the length of hospital stay with early colonoscopy.

Colonoscopy has been recommended as the first-line diagnostic procedure for LGIB [5], but questions remain regarding its timing and suitability for all patients.

We found that the use of CTA with colonoscopy may enhance the identification of bleeding lesions when compared with colonoscopy alone. Although this did translate into increased use of hemostatic therapy, there was no or minimal impact upon clinically important outcomes such as rebleeding or transfusion. CTA is often reserved for unstable patients that do not respond to resuscitation [5], but we found no studies comparing it with other interventions in exclusively shocked patients.

Although colonoscopy performed within 24 hours of admission was associated with higher rates of diagnosis, hemostasis, and a reduction in length of hospital stay, there was no evidence that it had any impact upon death or rebleeding. Paradoxically, there was higher red blood cell transfusion in the early colonoscopy arm of the RCT, although this may represent baseline imbalances between arms, as the initial hemoglobin was also lower in the early arm [29]. Most of the studies on timing of colonoscopy were nonrandomized, and conducted in patients who were subsequently diagnosed with diverticular bleeding, limiting the generalizability of these findings. Timing of colonoscopy has been the focus of three recent systematic reviews. Kouanda et al. and Seth et al. included RCTs and cohort studies, but differed in their classification of several large database studies that we rejected as case series, or restricted their search to English language studies [31,32]. Nonetheless, the authors reported similar findings: there was no difference in rates of rebleeding, death or transfusion. In contrast to the present review, Seth et al. reported that there was no difference in therapeutic yield or hospital stay with early colonoscopy. For therapeutic yield, the authors did not include data from Albeldawi et al. in the meta-analysis, but the reasons for this are not clear. For length of hospital stay, the authors pooled estimates from RCTs with NRSIs, which may account for the different findings from the current review. Sengupta et al. used a similar study classification system to that used in the present review, and also pooled estimates from RCTs and NRSIs, but also reported no difference in clinical outcomes with early colonoscopy [15].

The use of colonoscopy in real-life practice is variable. In a recent nationwide audit of 143 hospitals in the UK, colonoscopy was performed in only $4 \%$ patients with LGIB, with a median waiting time of 4 days (range $2-8$ ) [33]. As there were no major barriers identified to the routine availability of colonoscopy, this is likely to reflect uncertainty regarding its utility in the acute setting. In contrast to upper GI bleeding, colonoscopy in the acute setting can be challenging to perform, requires rapid bowel preparation, and may be poorly tolerated by the patient. Only two studies reported complications, but overall early colonoscopy appeared to be safe. In one RCT, two patients who received urgent colonoscopy died [29]. Although neither was attributed to the intervention, the potential to cause harm in patients with extensive co-morbidities should not be underestimated.

The impact of early colonoscopy on hospital stay has clear benefits. A microcosting analysis of upper Gl bleeding admissions reported an average cost of $£ 2458$ per patient, most of which was due to the cost of the hospital bed [34]. Not all patients with LGIB will require urgent investigation, however. In the UK, $48 \%$ of admitted patients have a benign course and require no inpatient investigation [33]. The most frequent outpatient investigation is lower Gl endoscopy, $70 \%$ of which is scheduled to be performed more than 2 weeks post-discharge [33]. The value of such delayed intervention requires further research.

Outcomes other than length of hospital stay must also be considered. Rebleeding following endoscopic hemostasis was reported in $6 \%-48 \%$ patients in the cohort studies [17,22, 27 ], raising questions regarding the efficacy of endoscopic he- 
mostasis. This is important given the absence of evidence comparing it with other treatment options, notably embolization. The two studies comparing modes of endoscopic hemostasis were limited to patients with diverticular bleeding. Considering that bleeding stops spontaneously in over $80 \%$ of patients [35], this may not be the group that will derive the most benefit.

There are important questions regarding the value of colonoscopy in LGIB beyond diagnosis. Most therapeutic techniques originate in the upper $\mathrm{Gl}$ tract and may be unsuitable for lesions in the colon and rectum. Endotherapy relies on the identification of stigmata of recent hemorrhage to localize and treat the bleeding source, but this can be subjective, as demonstrated by the differing diagnostic yields between lesions that were defined as a presumptive vs. a definitive source. This is particularly relevant to diverticular bleeding, the most common cause of LGIB in the UK [33]. It can be difficult to identify the culprit diverticula, and treatment of one will not guarantee prevention of bleeding from another. Evaluation of the current management of LGIB is limited by the lack of baseline data for comparison: national observational studies have only been conducted since $2000[1,33,36]$, and there are currently no national guidelines on the management of LGIB in the UK. It is therefore not possible to compare current management with historical practice and to establish whether newer interventions such as CTA have made an impact.

There are several limitations to this review. Most evidence originates from NRSIs, with significant bias, which limits the strength of the conclusions that can be drawn from the review. More randomized data, particularly on the timing of colonoscopy, are urgently required, especially in view of the recent publication of risk scores focussing on increasing the outpatient management of LGIB [37]. Systematic review of NRSIs is limited by the variable description of study methodology, making their classification difficult. This is evidenced by the different studies that are included in reviews of the same topic with similar inclusion criteria [15, 31, 32]. A new study comparing CTA with colonoscopy was published [38] after the searches for the current review were completed in 2015 , and the results may be relevant to this topic and warrant an update of the present review in the future. We limited the search to studies published since 2000 , as before this date routine use of endotherapy and embolization were in their infancy, and studies were mostly limited to case reports and safety studies. Relevant studies published prior to this period may have been missed therefore.

In summary, although there was a paucity of high-quality evidence across most interventions, we found that colonoscopy within 24 hours had higher diagnostic and therapeutic yields, and a shorter hospital stay. The value of colonoscopy after hospital discharge requires further appraisal, in addition to further research into the identification of patients who will gain the greatest benefit from early colonoscopy. Additional areas of research should focus on the clinical outcomes of endoscopic hemostasis, particularly comparisons with mesenteric embolization.

\section{Acknowledgment}

James East was supported by the National Institute for Health Research (NIHR) Oxford Biomedical Research Centre (BRC). The views expressed are those of the author(s) and not necessarily those of the NHS, the NIHR or the Department of Health.

\section{Competing interests}

None

References

[1] Lanas A, Garcia-Rodriguez LA, Polo-Tomas M et al. Time trends and impact of upper and lower gastrointestinal bleeding and perforation in clinical practice. Am J Gastroenterol 2009; 104: 1633 - 1641

[2] Scheffel H, Pfammatter T, Wildi S et al. Acute gastrointestinal bleeding: detection of source and etiology with multi-detector-row CT. Eur Radiol 2007; 17: 1555 - 1565

[3] Cardin F, Andreotti A, Martella B et al. Current practice in colonoscopy in the elderly. Aging Clin Exp Res 2012; 24: 9-13

[4] Green BT, Rockey DC, Portwood G et al. Urgent colonoscopy for evaluation and management of acute lower gastrointestinal hemorrhage: a randomized controlled trial. Am J Gastroenterol 2005; 100: 2395 2402

[5] Strate LL, Gralnek IM. ACG Clinical Guideline: Management of patients with acute lower gastrointestinal bleeding. Am J Gastroenterol 2016; 111: 459-474 Erratum in Am J Gastroenterol 2016; 111: 755

[6] Strate LL, Naumann CR. The role of colonoscopy and radiological procedures in the management of acute lower intestinal bleeding. Clin Gastroenterol Hepatol 2010; 8: 333-343

[7] Koh FH, Soong J, Lieske B et al. Does the timing of an invasive mesenteric angiography following a positive $\mathrm{CT}$ mesenteric angiography make a difference? Int J Colorectal Dis 2015; 30: 57-61

[8] Moher D, Liberati A, Tetzlaff J et al. Preferred reporting items for systematic reviews and meta-analyses: the PRISMA statement. Ann Intern Med 2009; 151: 264-269, w264

[9] Stroup DF, Berlin JA, Morton SC et al. Meta-analysis of observational studies in epidemiology: a proposal for reporting. Meta-analysis Of Observational Studies in Epidemiology (MOOSE) group. JAMA 2000; 283: $2008-2012$

[10] Dekkers OM, Egger M, Altman DG et al. Distinguishing case series from cohort studies. Ann Intern Med 2012; 156: 37-40

[11] Gralnek IM, Neeman Z, Strate LL. Acute lower gastrointestinal bleeding. NEJM 2017; 376: 1054-1063

[12] Raju GS, Gerson L, Das A et al. American Gastroenterological Association (AGA) Institute technical review on obscure gastrointestinal bleeding. Gastroenterology 2007; 133: 1697-1717

[13] Higgins JGS. Cochrane handbook for systematic reviews of interventions. Cochrane Book Series 2008: 392-432

[14] Stang A. Critical evaluation of the Newcastle-Ottawa scale for the assessment of the quality of nonrandomized studies in meta-analyses. Eur J Epidemiol 2010; 25: 603-605

[15] Sengupta N, Tapper EB, Feuerstein JD. Early versus delayed colonoscopy in hospitalized patients with lower gastrointestinal bleeding: a meta-analysis. Clin J Gastroenterol 2017; 51: 352-359

[16] Higgins JP, Thompson SG, Deeks J] et al. Measuring inconsistency in meta-analyses. BMJ 2003; 327: 557-560 
[17] Ishii N, Fujita Y. Endoscopic treatment for colonic diverticular hemorrhage: from endoscopic clipping to endoscopic band ligation. Gastrointest Endosc 2011; 73: AB292

[18] Ketwaroo GA, Tewani SK, Kheraj R et al. Mesenteric CT angiography in the evaluation and management of acute lower GI bleeding. Gastroenterology 2012; 142: S581

[19] Rodriguez-Moranta F, Berrozpe A, Botargues JM et al. Colonoscopy delay in lower gastrointestinal bleeding: influence on diagnostic accuracy, endoscopic therapy and hospital stay. Gastrointest Endosc 2007; 65: AB261

[20] Sun J, Khandelwal N, Wong R. CT angiography is superior to tagged red blood cell scanning for localizing $\mathrm{GI}$ bleeding and for guiding management. Am J Gastroenterol 2011; 106: S82

[21] Yabutani A, Tomisato K, Teramoto A et al. Possible utility of contract enhanced computed tomography for detecting colonic diverticular bleeding by emergent colonoscopy. J Gastroenterol Hepatol 2014; 29: (Suppl. 03): $307-308$

[22] Nakano K, Ishii N, Fujita Y. Long-term outcomes of endoscopic band ligation versus endoscopic clipping for treatment of colonic diverticular hemorrhage. Gastrointest Endosc 2015; 81: AB370

[23] Yamaguchi T, Manabe N, Hata J et al. The usefulness of transabdominal ultrasound for the diagnosis of lower gastrointestinal bleeding. Aliment Pharmacol Ther 2006; 23: 1267-1272

[24] Albeldawi M, Ha D, Mehta P et al. Utility of urgent colonoscopy in acute lower gastro-intestinal bleeding: a single-center experience. Gastroenterol Rep 2014; 2: $300-305$

[25] Jacovides CL, Nadolski G, Allen SR et al. Arteriography for lower gastrointestinal hemorrhage: role of preceding abdominal computed tomographic angiogram in diagnosis and localization. JAMA Surgery 2015; 150: 650-656

[26] Nagata N, Niikura R, Aoki T et al. Role of urgent contrast-enhanced multidetector computed tomography for acute lower gastrointestinal bleeding in patients undergoing early colonoscopy. J Gastroenterol 2015; 50: $1162-1172$

[27] Nagata N, Niikura R, Sakurai T et al. Safety and effectiveness of early colonoscopy in management of acute lower gastrointestinal bleeding on the basis of propensity score matching analysis. Clin Gastroenterol Hepatol 2016; 14: 558 - 564

[28] Strate LL, Syngal S. Timing of colonoscopy: impact on length of hospital stay in patients with acute lower intestinal bleeding. Am J Gastroenterol 2003; 98: 317-322

[29] Laine L, Shah A. Randomized trial of urgent vs. elective colonoscopy in patients hospitalized with lower GI bleeding. Am J Gastroenterol 2010; 105: $2636-2641$

[30] Jensen DM, Machicado GA, Jutabha R et al. Urgent colonoscopy for the diagnosis and treatment of severe diverticular hemorrhage. NEJM 2000; 342: $78-82$

[31] Kouanda AM, Somsouk M, Sewell JL et al. Urgent colonoscopy in patients with lower gastrointestinal bleeding: a systematic review and meta-analysis. Gastrointest Endosc 2017; 86: 107 - 117 e1

[32] Seth A, Khan MA, Nollan R et al. Does urgent colonoscopy improve outcomes in the management of lower gastrointestinal bleeding? Am J Med Sci 2017; 353: 298-306

[33] Oakland K, Guy R, Uberoi R et al. Acute lower GI bleeding in the UK: patient characteristics, interventions and outcomes in the first nationwide audit. Gut 2017: doi:10.1136/gutjnl-2016-313428

[34] Campbell HE, Stokes EA, Bargo D et al. Costs and quality of life associated with acute upper gastrointestinal bleeding in the UK: cohort analysis of patients in a cluster randomised trial. BMJ Open 2015; 5: e007230

[35] Cirocchi R, Grassi V, Cavaliere D et al. New trends in acute management of colonic diverticular bleeding: a systematic review. Medicine 2015; 94: e1710

[36] Strate LL, Ayanian JZ, Kotler G et al. Risk factors for mortality in lower intestinal bleeding. Clin Gastroenterol Hepatol 2008; 6: 1004-1010

[37] Oakland K, Jairath V, Uberoi R et al. Derivation and validation of a novel risk score for safe discharge after acute lower gastrointestinal bleeding: a modelling study. Lancet Gastroenterol Hepatol 2017: doi:10.1016/s2468-1253(17)30150-4

[38] Clerc D, Grass F, Schafer M et al. Lower gastrointestinal bleeding computed tomographic angiography, colonoscopy or both? World J Emerg Surg 2017; 12: 1 


\section{Appendix 1: Search strategy}

The following databases were searched for systematic reviews, RCTs and observational (cohort) studies, from 2000 onwards, on 12.11.15:

MEDLINE (OvidSP, 1946 onwards)

PubMed (epublications only)

Embase (OvidSP, 1974 onwards)

CDSR, CENTRAL, DARE, HTA \& NHSEED (The Cochrane Library 2015, Issue 3)

Transfusion Evidence Library

Ongoing Trials:

ClinicalTrials.gov 159 refs

WHO International Clinical Trials Registry Platform: 36 refs

\section{N.B. The Data Providers of the ICTRP Search Portal currently} are:

Australian New Zealand Clinical Trials Registry (ANZCTR)

Brazilian Clinical Trials Registry (ReBec)

Chinese Clinical Trial Register (ChiCTR)

Clinical Research Information Service (CRiS), Republic of Korea

ClinicalTrials.gov

Clinical Trials Registry - India (CTRI)

Cuban Public Registry of Clinical Trials (RPCEC)

EU Clinical Trials Register (EU-CTR)

German Clinical Trials Register (DRKS)

Iranian Registry of Clinical Trials (IRCT)

ISRCTN.org

Japan Primary Registries Network (JPRN)

Pan African Clinical Trial Registry (PACTR)

Sri Lanka Clinical Trials Registry (SLCTR)

The Netherlands National Trial Register (NTR)

Searches retrieved 10,667 references plus 195 ongoing trials, which were reduced to 8,260 refs plus 87 ongoing trials when duplicates had been removed.

\section{SEARCH STRATEGIES}

MEDLINE (OvidSP)

1. exp Lower Gastrointestinal Tract/

2. exp Intestines/

3. Gastrointestinal Tract/

4. exp Mesenteric Arteries/

5. (lower gastrointestinal tract* or lower gastro-intestinal tract* or lower GI tract* or large intestin* or small intestin* or mesenteric arter*).tw,kf.

6. or/1-5

7. (h?emorrhag* or bleed* or re-bleed* or rebleed* or blood loss*).mp.

8. 6 and 7

9. $\exp$ Gastrointestinal Hemorrhage/

10. ((anal or anus or rectum or rectal or colon or colonic or colorectal or cecum or caecum or jejunum or cloaca or gut or ileum or diverticula* or lower intestin* or large intestin* or small intestin* or bowel or lower gastrointestinal or lower gastro-intestinal or lower GI or mesenteric) adj6 (h?emorrhag* or bleed* or re-bleed* or rebleed* or blood loss $\left.\left.{ }^{*}\right)\right)$.tw, kf.

11. (hematochezia or mel?ena or colonic angiodysplasia or proctorrhagi* or rectocolic* or rectorrhagi*).tw,kf.

12. or $/ 8-11$

13. exp Colonoscopy/

14. Proctoscopy/

15. (colonoscop* or coloscop* or sigmoidoscop* or proctoscop* or rectoscop* or enteroscop* or anuscop*).tw,kf.

16. Endoscopy, Gastrointestinal/

17. Capsule Endoscopy/

18. (endoscop* adj3 (capsule or video or lower or mesenteric or colon* or bowel)).tw,kf.

19. pillcam.tw,kf.

20. or/13-19

21. Colonography, Computed Tomographic/

22. ((CT or computed or tomograph* or virtual) adj2 (colonograph* or colonoscop* or pneumocolon*)).tw,kf.

23. Tomography, X-Ray Computed/

24. Radiology, Interventional/

25. (tomograph* angiogra* or CTA or CT angiogra* or mesenteric angiogra* or Gl angiogra* or (radiolog* adj2 (diagnos* or intervention*))).tw,kf.

26. Angiography/

27. or $/ 21-26$

28. Hemostasis, Endoscopic/

29. ((therap* or treatment* or h?emosta* or epinephrine or adrenaline or cyanoacrylate or inject* or band* or electrocauter* or argon plasma or thermal coagulat* or thermocoagulat* or thermo-coagulat* or heater probe* or argon coagulat* or laser coagulat* or YAG laser or ablat* or h?emoclip* or h?emospray or sclerotherap*) adj10 endoscop $\left.^{*}\right)$.tw, kf.

30. (endotherap* or endoclip* or over-the-scope clip*).tw,kf.

31. 20 or 28 or 29 or 30

32. Embolization, Therapeutic/

33. (emboli?ation or emboli?ed or embolotherap* or angioemboli* or microemoboli*).tw, kf.

34. 27 or 32 or 33

35. 12 and (31 or 34$)$

36. limit 35 to $y r=" 2000$-Current"

\section{EMBASE (OvidSP)}

1. exp Large Intestine/

2. exp Small Intestine/

3. $\exp$ Anus/

4. exp Mesenteric Artery/

5. Intestine/

6. Gastrointestinal Tract/

7. (lower gastrointestinal tract* or lower gastro-intestinal tract* or lower Gl tract* or large intestin* or small intestin* or mesenteric arter*).tw.

8. 1 or 2 or 4 or 5 or 6 or 7

9. (h?emorrhag* or bleed* or re-bleed* or rebleed* or blood loss $\left.{ }^{*}\right) \cdot \mathrm{mp}$.

10. Bleeding/ 
11. 9 or 10

12. 8 and 11

13. Gastrointestinal Hemorrhage/ or Colon Hemorrhage/ or Hemorrhagic Colitis/ or Intestinal Bleeding/ or Intestine Hematoma/ or Large Intestine Hemorrhage/ or Melena/ or Rectum Hemorrhage/ or Small Intestine Hemorrhage/

14. ((anal or anus or rectum or rectal or colon or colonic or colorectal or cecum or caecum or jejunum or cloaca or gut or ileum or diverticula* or lower intestin* or large intestin* or small intestin* or bowel or lower gastrointestinal or lower gastro-intestinal or lower GI or mesenteric) adj6 (h?emorrhag* or bleed* or re-bleed* or rebleed* or blood loss $\left.\left.{ }^{*}\right)\right)$.tw.

15. (hematochezia or mel?ena or colonic angiodysplasia or proctorrhagi* or rectocolic* or rectorrhagi*).tw.

16. or $/ 12-15$

17. Intestine Endoscopy/ or Capsule Endoscopy/ or Colonoscopy/ or Push Enteroscopy/ or Rectoscopy/ or Sigmoidoscopy/

18. Gastrointestinal Endoscopy/

19. (colonoscop* or coloscop* or sigmoidoscop* or proctoscop* or rectoscop* or enteroscop* or anuscop* or pillcam*).tw.

20. (endoscop* adj3 (capsule or video or lower or mesenteric or colon* or bowel)).tw.

21. or $/ 17-20$

22. * Endoscopy/ and *Hemostasis/

23. ((therap* or treatment* or h?emosta* or epinephrine or adrenaline or cyanoacrylate or inject* or banded or banding or electrocauter* or argon plasma or thermal coagulat* or thermocoagulat* or thermo-coagulat* or heater probe* or argon coagulat* or laser coagulat* or YAG laser or ablat* or h?emoclip* or h?emospray or sclerotherap*) adj10 endoscop*).tw.

24. (endotherap* or endoclip* or over-the-scope clip*).tw.

25. or $/ 21-24$

26. Computed Tomographic Colonography/

27. ((CT or computed or tomograph* or virtual) adj2 (colonograph* or colonoscop* or pneumocolon*)).tw.

28. Computer Assisted Tomography/

29. Interventional Radiology/

30. (tomograph* angiogra* or CTA or CT angiogra* or mesenteric angiogra* or Gl angiogra* or (radiolog* adj2 (diagnos* or intervention*))).tw.

31. Abdominal Angiography/ or Superior Mesenteric Angiography/

32. Pelvic Angiography/

33. or $/ 26-32$

34. Artificial Embolism/

35. (emboli?ation or emboli?ed or embolotherap* or angioemboli* or microemoboli*).tw.

36. or $/ 33-35$

37. 16 and ( 25 or 36$)$

PubMed (epublications only)

\#1 (lower gastrointestinal tract* OR lower gastro-intestinal tract* OR lower GI tract* OR large intestin* OR small intestin*
OR mesenteric arter*) AND (hemorrhag* OR haemorrhag* OR bleed* OR re-bleed* OR rebleed* OR blood loss*)

\#2 ((anal OR anus OR rectum OR rectal OR colon OR colonic OR colorectal OR cecum OR caecum OR jejunum OR cloaca OR gut OR ileum OR diverticula* OR lower intestin* OR large intestin* OR small intestin* OR bowel OR lower gastrointestinal OR lower gastro-intestinal OR lower GI OR mesenteric) AND (hemorrhag* OR haemorrhage* OR bleed* OR re-bleed* OR rebleed* OR blood loss*))

\#3 (hematochezia OR melena OR melaena OR colonic angiodysplasia OR proctorrhagi* OR rectocolic* OR rectorrhagi*)

\#4 \#1 OR \#2 OR \#3

\#5 (colonoscop* OR coloscop* OR sigmoidoscop* OR proctoscop* OR rectoscop* OR anuscop* OR pillcam OR endotherap* OR endoclip* OR over-the-scope clip*)

\#6 ((capsule OR video OR lower OR mesenteric OR colon OR colonic OR bowel OR hemosta* OR haemostat* OR epinephrine OR adrenaline OR cyanoacrylate OR inject* OR banded OR banding OR electrocauter* OR argon plasma OR thermal coagulat* OR thermocoagulat* OR thermo-coagulat* OR heater probe* OR argon coagulat* OR laser coagulat* OR YAG laser OR ablat* OR hemoclip* OR hemospray OR sclerotherap*) AND endoscop*)

\#7 \#5 OR \#6

\#8 ((CT OR computed OR tomograph* OR virtual) AND (colonograph* OR colonoscop* OR pneumocolon*))

\#9 (tomograph* angiogra* OR CTA OR CT angiogra* OR mesenteric angiogra* OR GI angiogra* OR (radiolog* AND (diagnos* OR intervention $\left.\left.{ }^{*}\right)\right)$ )

\#10 (embolization OR embolized OR embolization OR embolised OR embolotherap* OR angioemboli* OR microemoboli*)

\#11 \#8 OR \#9 OR \#10

\#12 \#4 and (\#7 OR \#11)

\#13 ((random* OR blind* OR "control group" OR placebo* OR controlled OR cohort* OR nonrandom* OR observational OR retrospective* OR prospective* OR comparative OR comparator OR groups OR trial* OR "systematic review" OR "metaanalysis" OR metaanalysis OR "literature search" OR medline OR cochrane OR embase) AND (publisher[sb] OR inprocess[sb] OR pubmednotmedline[sb]))

\#14 \#12 and \#13

\section{TRANSFUSION EVIDENCE LIBRARY}

Clinical Specialty: Gastrointestinal Disorders

Subject Area: Red Cells

\section{ClinicalTrials.gov}

Conditions/Search Terms: GI bleeding OR lower gastrointestinal hemorrhage OR colorectal bleeding OR colonic bleeding OR intestinal bleeding OR rectal bleeding OR mesenteric bleeding OR hematochezia OR melena OR bowel bleeding OR diverticular bleeding

Interventions: endoscopy OR colonoscopy OR CT OR tomography OR proctoscopy OR endoclip OR colonography OR angiography OR embolization OR capsule OR pillcam 


\section{ICTRP}

Conditions/Search Terms: GI bleeding OR lower gastrointestinal hemorrhage OR colorectal bleeding OR colonic bleeding OR intestinal bleeding OR rectal bleeding OR mesenteric bleeding OR hematochezia OR melena OR bowel bleeding OR diverticular bleeding

Interventions: endoscopy OR colonoscopy OR CT OR tomography OR proctoscopy OR endoclip OR colonography OR angiography OR embolization OR capsule OR pillcam

\section{Results}

Relevant references: 5850

Possibly irrelevant references: 2410 (contain one or more of the following words in the title: upper (not lower), abdominal aortic aneurysm, cancer, malignan*, carcinoma*, esophageal, duodenal, hepatic, cirrho*, stomach, liver, transplant*, varice*, pancreat*)

These have been screened by one reviewer $(\mathrm{KO})$ and identified 40 possible relevant references. These have been added to the 'relevant references' for full screening by two reviewers. 
Appendix 2: Study characteristics

\begin{tabular}{|c|c|c|c|c|c|c|c|c|c|c|}
\hline \multirow{2}{*}{$\begin{array}{l}\text { Study } \\
\text { (Coun- } \\
\text { try) } \\
\text { [ref] }\end{array}$} & \multirow[t]{2}{*}{ Design } & \multirow{2}{*}{$\begin{array}{l}\text { Study } \\
\text { years }\end{array}$} & \multirow{2}{*}{$\begin{array}{l}\text { Study } \\
\text { population }\end{array}$} & \multirow[t]{2}{*}{ Interventions } & \multirow{2}{*}{$\begin{array}{l}\text { Partici- } \\
\text { pants, } \\
\text { n }\end{array}$} & \multirow{2}{*}{$\begin{array}{l}\text { Age, } \\
\text { mean } \\
\pm S D \text {, } \\
\text { years }\end{array}$} & \multirow{2}{*}{$\begin{array}{l}\text { Shock*, } \\
\text { n (\%) }\end{array}$} & \multicolumn{3}{|c|}{ Medications on admission, $\mathrm{n}(\%)$} \\
\hline & & & & & & & & $\begin{array}{l}\text { Anticoa- } \\
\text { gulants }\end{array}$ & $\begin{array}{l}\text { Antiplate- } \\
\text { lets }\end{array}$ & NSAIDs \\
\hline \multirow{2}{*}{$\begin{array}{l}\text { Green } \\
2005 \\
\text { (USA) } \\
{[4]}\end{array}$} & \multirow[t]{2}{*}{ RCT } & \multirow[t]{2}{*}{$\begin{array}{l}1993- \\
1995\end{array}$} & \multirow{2}{*}{$\begin{array}{l}\text { Patients ad- } \\
\text { mitted with } \\
\text { hematoche- } \\
\text { zia with } \\
\text { clinical or } \\
\text { laboratory } \\
\text { evidence of } \\
\text { significant } \\
\text { blood loss }\end{array}$} & $\begin{array}{l}\text { Colonoscopy } \\
<8 \text { hours after } \\
\text { admission }\end{array}$ & 50 & $68 \pm 3$ & $30(60.0)$ & NR & NR & $29(60.0)$ \\
\hline & & & & $\begin{array}{l}\text { Standard care: } \\
\text { red cell scan if } \\
\text { ongoing bleed- } \\
\text { ing, colonosco- } \\
\text { py }\end{array}$ & 50 & $71 \pm 4$ & $34(68.0)$ & NR & NR & $26(52.0)$ \\
\hline \multirow{2}{*}{$\begin{array}{l}\text { Laine } \\
2010 \\
\text { (USA) } \\
{[29]}\end{array}$} & \multirow[t]{2}{*}{ RCT } & \multirow[t]{2}{*}{$\begin{array}{l}2002- \\
2008\end{array}$} & \multirow{2}{*}{$\begin{array}{l}\text { Patients ad- } \\
\text { mitted with } \\
\text { hematoche- } \\
\text { zia with a } \\
\text { high-risk } \\
\text { feature* }\end{array}$} & $\begin{array}{l}\text { Colonoscopy } \\
<12 \text { hours after } \\
\text { admission }\end{array}$ & 36 & $52 \pm 3$ & $27(75.0)$ & NR & NR & NR \\
\hline & & & & $\begin{array}{l}\text { Colonoscopy } \\
36-60 \text { hours } \\
\text { after admission }\end{array}$ & 36 & $52 \pm 2$ & $31(86.1)$ & NR & NR & NR \\
\hline \multirow{2}{*}{$\begin{array}{l}\text { Albeldawi } \\
2014 \\
\text { (USA) } \\
{[24]}\end{array}$} & \multirow[t]{2}{*}{$\begin{array}{l}\text { Retrospec- } \\
\text { tive cohort }\end{array}$} & \multirow[t]{2}{*}{$\begin{array}{l}2011- \\
2012\end{array}$} & \multirow[t]{2}{*}{$\begin{array}{l}\text { All acute } \\
\text { LGIB }\end{array}$} & $\begin{array}{l}\text { Colonoscopy } \\
<24 \text { hours after } \\
\text { admission }\end{array}$ & 24 & $\begin{array}{l}66.8 \pm \\
13.8\end{array}$ & NR & $2(8.3)$ & $13(54.2)$ & $2(8.3)$ \\
\hline & & & & $\begin{array}{l}\text { Colonoscopy } \\
>24 \text { hours after } \\
\text { admission }\end{array}$ & 33 & $\begin{array}{l}69.3 \pm \\
11.1\end{array}$ & NR & $7(21.2)$ & $19(57.6)$ & $3(9.1)$ \\
\hline \multirow{2}{*}{$\begin{array}{l}\text { Ishii } 2011 \\
\text { (Japan) } \\
{[17]}\end{array}$} & \multirow{2}{*}{$\begin{array}{l}\text { Retrospec- } \\
\text { tive cohort }\end{array}$} & \multirow{2}{*}{$\begin{array}{l}2004- \\
2010 \\
2009- \\
2010\end{array}$} & \multirow{2}{*}{$\begin{array}{l}\text { Patients with } \\
\text { colonic di- } \\
\text { verticular } \\
\text { hemorrhage }\end{array}$} & EBL & 16 & NR & NR & NR & NR & NR \\
\hline & & & & Endoclipping & 48 & NR & NR & NR & NR & NR \\
\hline \multirow[t]{2}{*}{$\begin{array}{l}\text { Jacovides } \\
2015 \\
\text { (USA) } \\
{[25]}\end{array}$} & \multirow[t]{2}{*}{$\begin{array}{l}\text { Historical } \\
\text { control }\end{array}$} & \multirow[t]{2}{*}{$\begin{array}{l}2005- \\
2012\end{array}$} & \multirow[t]{2}{*}{$\begin{array}{l}\text { All patients } \\
\text { hospitalized } \\
\text { with LGIB }\end{array}$} & $\begin{array}{l}\text { Historical pro- } \\
\text { tocol: red cell } \\
\text { scan, CTA or } \\
\text { colonoscopy }\end{array}$ & 78 & $68 \pm 15$ & NR & NR & NR & NR \\
\hline & & & & $\begin{array}{l}\text { New protocol: } \\
\text { CTA, colonos- } \\
\text { copy }\end{array}$ & 83 & $70 \pm 15$ & NR & NR & NR & NR \\
\hline \multirow[t]{2}{*}{$\begin{array}{l}\text { Jensen } \\
2000 \\
\text { (USA) } \\
{[30]}\end{array}$} & \multirow[t]{2}{*}{$\begin{array}{l}\text { Historical } \\
\text { control }\end{array}$} & \multirow{2}{*}{$\begin{array}{l}1986- \\
1992 \\
\text { and } \\
1994- \\
1998\end{array}$} & \multirow{2}{*}{$\begin{array}{l}\text { Patients with } \\
\text { hematoche- } \\
\text { zia and di- } \\
\text { verticulosis }\end{array}$} & $\begin{array}{l}\text { Medical and } \\
\text { surgical inter- } \\
\text { vention }\end{array}$ & 17 & $66 \pm 3$ & NR & NR & NR & 3 \\
\hline & & & & $\begin{array}{l}\text { Medical and } \\
\text { endoscopic } \\
\text { therapy }\end{array}$ & 10 & $67 \pm 4$ & $N R$ & $N R$ & NR & 3 \\
\hline \multirow{2}{*}{$\begin{array}{l}\text { Nagata } \\
2016 \\
\text { (Japan) } \\
{[27]}\end{array}$} & \multirow[t]{2}{*}{$\begin{array}{l}\text { Retrospec- } \\
\text { tive cohort }\end{array}$} & $\begin{array}{l}2009- \\
2014\end{array}$ & $\begin{array}{l}\text { All patients } \\
\text { admitted } \\
\text { with acute }\end{array}$ & $\begin{array}{l}\text { Colonoscopy } \\
<24 \text { hours after } \\
\text { admission }\end{array}$ & 163 & $\begin{array}{l}67.9 \pm \\
17.4\end{array}$ & $17(10.4)$ & $9(5.5)$ & $63(38.7)$ & $23(14.1)$ \\
\hline & & & overt LGIB & $\begin{array}{l}\text { Colonoscopy } \\
>24 \text { hours after } \\
\text { admission }\end{array}$ & 163 & $\begin{array}{l}66.4 \pm \\
16.9\end{array}$ & $19(11.7)$ & $6(11.7)$ & $54(33.1)$ & $20(12.3)$ \\
\hline $\begin{array}{l}\text { Nagata } \\
2015 \\
\text { (Japan) }\end{array}$ & $\begin{array}{l}\text { Retrospec- } \\
\text { tive Cohort }\end{array}$ & $\begin{array}{l}2008- \\
2013\end{array}$ & $\begin{array}{l}\text { Patients ad- } \\
\text { mitted with } \\
\text { LGIB who un- }\end{array}$ & $\begin{array}{l}\text { Urgent CTA } \\
\text { then colonosco- } \\
\text { py }\end{array}$ & 126 & $\begin{array}{l}68.3 \pm \\
16.5\end{array}$ & $5(4.0)$ & $7(5.6)$ & $55(43.7)$ & 33 \\
\hline [26] & & & $\begin{array}{l}\text { derwent co- } \\
\text { lonoscopy }\end{array}$ & $\begin{array}{l}\text { Colonoscopy } \\
<24 \text { hours after } \\
\text { admission }\end{array}$ & 97 & $\begin{array}{l}67.7 \pm \\
16.5\end{array}$ & $1(1.0)$ & $4(4.1)$ & $36(37.1)$ & $13(13.4)$ \\
\hline
\end{tabular}


(Continuation)

\begin{tabular}{|c|c|c|c|c|c|c|c|c|c|c|}
\hline \multirow{2}{*}{$\begin{array}{l}\text { Study } \\
\text { (Coun- } \\
\text { try) } \\
\text { [ref] }\end{array}$} & \multirow[t]{2}{*}{ Design } & \multirow{2}{*}{$\begin{array}{l}\text { Study } \\
\text { years }\end{array}$} & \multirow{2}{*}{$\begin{array}{l}\text { Study } \\
\text { population }\end{array}$} & \multirow[t]{2}{*}{ Interventions } & \multirow{2}{*}{$\begin{array}{l}\text { Partici- } \\
\text { pants, } \\
\text { n }\end{array}$} & \multirow{2}{*}{$\begin{array}{l}\text { Age, } \\
\text { mean } \\
\pm S D \\
\text { years }\end{array}$} & \multirow{2}{*}{$\begin{array}{l}\text { Shock*, } \\
\text { n (\%) }\end{array}$} & \multicolumn{3}{|c|}{ Medications on admission, $\mathbf{n}(\%)$} \\
\hline & & & & & & & & $\begin{array}{l}\text { Anticoa- } \\
\text { gulants }\end{array}$ & $\begin{array}{l}\text { Antiplate- } \\
\text { lets }\end{array}$ & NSAIDs \\
\hline \multirow{2}{*}{$\begin{array}{l}\text { Nakano } \\
2015 \\
\text { (Japan) } \\
{[22]}\end{array}$} & \multirow{2}{*}{$\begin{array}{l}\text { Retrospec- } \\
\text { tive cohort }\end{array}$} & \multirow{2}{*}{$\begin{array}{l}2004- \\
2014\end{array}$} & \multirow[b]{2}{*}{$\begin{array}{l}\text { Patients un- } \\
\text { dergoing } \\
\text { endoscopic } \\
\text { therapy for } \\
\text { colonic di- } \\
\text { verticular } \\
\text { hemorrhage }\end{array}$} & EBL & 50 & $67 \pm 13$ & NR & NR & 15 & 4 \\
\hline & & & & Endoclipping & 39 & $64 \pm 13$ & NR & NR & 13 & 3 \\
\hline \multirow{2}{*}{$\begin{array}{l}\text { Sun } 2011 \\
\text { (USA) } \\
{[20]}\end{array}$} & \multirow{2}{*}{$\begin{array}{l}\text { Retrospec- } \\
\text { tive cohort }\end{array}$} & \multirow{2}{*}{$\begin{array}{l}2007- \\
2008 \\
\text { and } \\
2008- \\
2010\end{array}$} & \multirow{2}{*}{$\begin{array}{l}\text { All patients } \\
\text { hospitalized } \\
\text { with acute GI } \\
\text { bleeding }\end{array}$} & CTA & 53 & NR & NR & NR & NR & NR \\
\hline & & & & Red cell scan & 46 & NR & NR & NR & NR & NR \\
\hline $\begin{array}{l}\text { Yabutani } \\
2014 \\
\text { (Japan) } \\
{[21]}\end{array}$ & $\begin{array}{l}\text { Single ret- } \\
\text { rospective } \\
\text { cohort }\end{array}$ & $\begin{array}{l}2010- \\
2012\end{array}$ & $\begin{array}{l}\text { Patients di- } \\
\text { agnosed } \\
\text { with diverti- } \\
\text { cular bleed- } \\
\text { ing }\end{array}$ & $\begin{array}{l}\text { CTA and colo- } \\
\text { noscopy }\end{array}$ & 57 & NR & NR & NR & NR & NR \\
\hline $\begin{array}{l}\text { Yamagu- } \\
\text { chi } 2006 \\
\text { (Japan) } \\
{[23]}\end{array}$ & $\begin{array}{l}\text { Single ret- } \\
\text { rospective } \\
\text { cohort }\end{array}$ & $\begin{array}{l}1999- \\
2004\end{array}$ & $\begin{array}{l}\text { Consecutive } \\
\text { patients with } \\
\text { hematoche- } \\
\text { zia }\end{array}$ & $\begin{array}{l}\text { Ultrasound and } \\
\text { colonoscopy }\end{array}$ & 111 & $\begin{array}{l}58 \text { (range } \\
18-96 \text { ) }\end{array}$ & NR & NR & NR & NR \\
\hline \multirow{2}{*}{$\begin{array}{l}\text { Ketwaroo } \\
2012 \\
\text { (USA) } \\
{[18]}\end{array}$} & \multirow{2}{*}{$\begin{array}{l}\text { Retrospec- } \\
\text { tive cohort }\end{array}$} & \multirow{2}{*}{$\begin{array}{l}2010- \\
2011\end{array}$} & \multirow{2}{*}{$\begin{array}{l}\text { Suspected } \\
\text { acute LGIB }\end{array}$} & CTA & 46 & $68.2 \pm 17$ & NR & NR & NR & NR \\
\hline & & & & Red cell scan & 46 & $70 \pm 15$ & NR & NR & NR & NR \\
\hline \multirow{2}{*}{$\begin{array}{l}\text { Strate } \\
2003 \\
\text { (USA) } \\
{[28]}\end{array}$} & \multirow[t]{2}{*}{$\begin{array}{l}\text { Retrospec- } \\
\text { tive cohort } \\
\text { - subgroup }\end{array}$} & \multirow[t]{2}{*}{$\begin{array}{l}1996- \\
1999\end{array}$} & \multirow{2}{*}{$\begin{array}{l}\text { All patients } \\
\text { admitted } \\
\text { with ICD-9 } \\
\text { codes repre- } \\
\text { senting LGIB, } \\
\text { or a wide } \\
\text { range of di- } \\
\text { agnoses } \\
\text { associated } \\
\text { with LGIB }\end{array}$} & $\begin{array}{l}\text { Colonoscopy } \\
<24 \text { hours after } \\
\text { admission }\end{array}$ & 69 & NR & NR & NR & NR & NR \\
\hline & & & & $\begin{array}{l}\text { Colonoscopy } \\
>24 \text { hours after } \\
\text { admission }\end{array}$ & 75 & NR & NR & NR & NR & NR \\
\hline \multirow{2}{*}{$\begin{array}{l}\text { Rodri- } \\
\text { guez- } \\
\text { Moranta } \\
2007 \\
\text { (Spain) } \\
19]\end{array}$} & \multirow[t]{2}{*}{$\begin{array}{l}\text { Prospec- } \\
\text { tive cohort }\end{array}$} & \multirow[t]{2}{*}{$\begin{array}{l}2005- \\
2006\end{array}$} & \multirow{2}{*}{$\begin{array}{l}\text { Consecutive } \\
\text { patients ad- } \\
\text { mitted with } \\
\text { LGIB }\end{array}$} & $\begin{array}{l}\text { Colonoscopy } \\
<24 \text { hours after } \\
\text { admission }\end{array}$ & 92 & NR & NR & NR & NR & NR \\
\hline & & & & $\begin{array}{l}\text { Colonoscopy } \\
>24 \text { hours after } \\
\text { admission }\end{array}$ & 88 & NR & NR & NR & NR & NR \\
\hline $\begin{array}{l}\text { CTA, comp } \\
\text { tinal bleed } \\
{ }^{*} \text { High risk } \\
>20 \text { beat }\end{array}$ & $\begin{array}{l}\text { uted tomograp } \\
\text { ing; NR, not rep } \\
\text { features define } \\
\text { s/min, blood tr }\end{array}$ & $\begin{array}{l}\text { nic angiog } \\
\text { orted; NSA } \\
\text { d as heart } \\
\text { insfusion, }\end{array}$ & $\begin{array}{l}\text { hy; EBL, endoscc } \\
\text { nonsteroidal an } \\
\text { p }>100, \text { systolic } \\
\text { Irop in hemoglo }\end{array}$ & $\begin{array}{l}\text { pic band ligation; } \mathrm{G} \\
\text { ti-inflammatory dru } \\
\text { lood pressure }<100 \\
\text { in } \geq 1.5 \mathrm{~g} / \mathrm{dL} \text { within }\end{array}$ & $\begin{array}{l}\text { jastrointe } \\
\text { RCT, ranc } \\
\text { mHg, ort } \\
\text { 5-hour pe }\end{array}$ & $\begin{array}{l}\text { al; ICD, Interı } \\
\text { ized controlle } \\
\text { atic changes } \\
\text {. }\end{array}$ & $\begin{array}{l}\text { ational Clas } \\
\text { trial } \\
\text { n systolic bl }\end{array}$ & $\begin{array}{l}\text { cation of } \mathrm{Di} \\
\mathrm{d} \text { pressure }\end{array}$ & $\begin{array}{l}\text {; LGIB, lower } \\
\mathrm{mHg} \text { or in hea }\end{array}$ & $\begin{array}{l}\text { strointes- } \\
\text { rate }\end{array}$ \\
\hline
\end{tabular}

